\title{
Preliminary Phytochemical Analysis and in Vitro Evaluation of Antifungal Activity of Five Invasive Plant Species against Macrophomina Phaseolina (Tassi) Goid
}

\author{
S. Rashmi, H. G. Rajkumar* \\ Department of Studies in Botany, University of Mysore, Manasagangotri, MYSORE, 570006, Karnataka State, India
}

\begin{abstract}
In vitro antifungal activity of leaf extract of five invasive plant species were evaluated against the fungal pathogen Macrophomina phaseolina using Microdilution assay and direct bioautographic technique. Plants selected for investigations were Ageratum conyzoides, Antigonon leptopus, Chromolaena odorata, Oxalis corniculata and Passiflora foetida. Methanolic extract of all the plants exhibited good activity with minimum inhibitory concentration (MIC) values ranged between $0.078-2.5 \mathrm{mg} / \mathrm{ml}$. The leaf extract of Oxalis corniculata had promising antifungal activity with a low MIC value of $0.078 \mathrm{mg} / \mathrm{ml}$ compared to the other species extracts tested. Total activity was highest in Antigonon leptopus $(2304 \mathrm{ml} / \mathrm{g}$ ) followed by Oxalis corniculata $(2141 \mathrm{ml} / \mathrm{g})$. Bioautography indicated clear zones of inhibition in Antigonon leptopus extract with three active band at $R_{f}$ value of $0.779,0.468$ and 0.276 in BEA mobile system and fungal growth was inhibited in most of the plants tested.
\end{abstract}

Keywords Antigonon Leptopus, Direct Bioautography, Microdilution Assay, Oxalis Corniculata

\section{Introduction}

An invasive species defined by IUCN (2000) as "Species which becomes established in natural or semi-natural ecosystems or habitat, is an agent of cause, and threatens native biological diversity"[1]. An invasive plant, also referred to as exotic, introduced, foreign, non-indigenous or non-native, is one that has been introduced by humans intentionally or otherwise through human agency or accidently from one region to another. In India, a good number of high-value biodiversity sites have been invaded by several invasive alien plants[2].Total 173 species in 117 genera under 44 families were documented as invasive alien plant species, representing $1 \%$ of Indian flora[3].

Invasive plants are naturalized plants that produce reproductive offspring, often in very large numbers, at considerable distances from parent plants and thus have the potential to spread over a considerable area[4].Invasive alien species reduce biodiversity, replace economically important native plant species and decrease the investment in agriculture and silviculture, disrupt prevailing vegetation dynamics, alter nutrient cycling and cause changes in the pattern of plant succession. Several exotic plants have invaded the high-value biodiversity areas and have adversely affected

* Corresponding author:

rajkumarhg@yahoo.co.in (H. G. Rajkumar)

Published online at http://journal.sapub.org/plant

Copyright (C) 2011 Scientific \& Academic Publishing. All Rights Reserved the natural and semi-natural vegeta tion/ecosystems[5].Farm -ers, taxonomists and ecologist are now well aware of the invasion of alien species into natural areas and associated negative effects on Global patterns of native biodiversity. Once established some alien species have the ability to displace or replace native plant species the problem will likely worsen with time because of climatic changes that promote species migration worldwide.

From the earlier reports $[6,7]$ it is evident that some of the invasive plants have antifungal compounds which do have the capacity to inhibit the fungal pathogens. Plant fungal pathogens in particular, pose a major threat to economically valuable crops. Plant pathogenic fungi attack most crops in the field and also post harvest thereby decreasing production and shelf life of many agricultural crops[8] .The most important method of protecting plants against fungal attack is the use of fungicides.

The development of resistance of pathogenic fungi towards synthetic fungicides is of great concern. There is, therefore, a motivation to find safe, efficacious and environmentally friendly fungicides. Many plants produce antifungal agents by secondary metabolism to protect themselves from fungal attack, and therefore many plant species posses substantial antifungal activity. Thus, the use of plant extracts with inhibitory activity against fungal plant pathogens could lead to the development of environmentally acceptable fungicides based on the availability of natural products. If fungal pathogen plays an important role in the growth or establishment of plant species, invasive species 
may have better resistance against plant pathogens[6].

Many invasive plant species release chemical compounds into the environment, which are not generally harmful to them, but those chemicals suppress the growth of other plant species growing in close proximity of such invasive species. Prime importance can be given for the bioprospecting of novel active compound which can be utilized for the management of several plant diseases. This negative effect (often referred to as allelopathic effect) of invaders on the native species confers a tremendous competitive advantage on the former. Many reports are available on inhibiting fungal pathogen from plant extracts[7, 9-14]. The invasive plants are easily available throughout the year and are found growing around the crop lands. This will enable the farmers to use these plants in crop protection against various phytopathogenic diseases. Hence, the present work is aimed to investigate invasive plant species for antifungal activity against plant pathogens in order to develop a useful product.

\section{Materials and Methods}

\subsection{Plant Collection}

The invasive plants species selected to work were collected in Mysore region, Karnataka, India. Leaves of the plants Ageratum conyzoides L., Antigonon leptopus Hook. \& Arn., Chromolaena odorata(L.) R.M.King \& H.Rob., Oxalis corniculata L. and Passiflora foetida L. were collected in the summer of 2010. Fresh healthy leaves were separated from stems, thoroughly washed 2-3 times with water and shade dried at room temperature. The dried plants were milled to a fine power with the help of a blender and stored at room temperature in closed containers in the dark until used. Voucher specimen was deposited in the herbarium of the Department of studies in Botany, Manasagangotri, University of Mysore, Karnataka.

\subsection{Extraction Procedure}

Plant samples from each species were individually extracted by soaking $10 \mathrm{~g}$ of finely ground plant material with $100 \mathrm{ml}$ of Chloroform and Methanol solvents separately in conical flasks, plugged with cotton and kept on a rotary shaker at 180-200rpm for $24 \mathrm{hrs}$. It was filtered through 3 layered muslin cloths and the supernatant was filtered through Whatman No.1 filter paper. Each of the solvent extract was concentrated separately under reduced pressure. After complete solvent evaporation, each of the solvent extract was weighed and preserved at $5^{\circ} \mathrm{C}$ in air tight bottles until further use.

\subsection{Preliminary Phytochemical Analysis}

Phytochemical tests were carried out to detect the presence of particular compounds using standard procedure[15].

Detection of Tannins: 200mg plant material is taken in $10 \mathrm{ml}$ distilled water and filtered. A $2 \mathrm{ml}$ filtrate is added to $2 \mathrm{ml} \mathrm{FeCl}_{3}$; blue- black precipitate indicates the presence of tannins.

Detection of Alkaloids: Dragondroff's test; $200 \mathrm{mg}$ plant material is taken in $10 \mathrm{ml}$ methanol and filtered. A $2 \mathrm{ml}$ filtrate is added to $1 \% \mathrm{HCl}$, steam for 10 minutes. To this add 6 drops of Dragondroff's reagent; Reddish brown precipitate indicates the presence of alkaloids.

Detection of Saponins: Frothing test; $1 \mathrm{ml}$ of methanol extract was diluted with $20 \mathrm{ml}$ distilled water and shaken well for 15 minutes and observed for formation of froth in the upper layer. The presence of froth indicates the presence of saponins.

Detection of Cardiac Glycosides: Keller-kiliani test; $2 \mathrm{ml}$ of methanol extract is added to $1 \mathrm{ml}$ glacial acetic acid, to this mixture few drops of $\mathrm{FeCl}_{3}$ and one drop of conc. $\mathrm{H}_{2} \mathrm{SO}_{4}$ is added. Green blue colour indicated the presence of cardiac glycosides.

Detection of Steroids: Liebermann-Burchard reaction; $200 \mathrm{mg}$ plant material is taken in $10 \mathrm{ml}$ chloroform and filtered .A $2 \mathrm{ml}$ filtrate is taken, to this $2 \mathrm{ml}$ acetic anhydrate and few drops of conc. $\mathrm{H}_{2} \mathrm{SO}_{4}$ is added. Blue-green ring indicates the presence of steroids.

Detection of Flavanoids: $\mathrm{NaOH}$ solution test; $2 \mathrm{ml}$ of methanol extract is added to $2 \mathrm{ml}$ of $10 \% \mathrm{NaOH}$ solution. Yellow to orange colour indicates the presence of flavanoids.

Detection of Proteins: Xanthoproteic test; $1 \mathrm{ml}$ of extract is added to $1 \mathrm{ml}$ of $\mathrm{HNO}_{3}$, boil in a water bath. Orange colour indicates the presence of proteins.

Detection of Triterpenes: Salkowski test; $200 \mathrm{mg}$ of plant material is added to $2 \mathrm{ml}$ of chloroform with few drops of conc. $\mathrm{H}_{2} \mathrm{SO}_{4}$. The solution slowly turns red, indicates the presence of triterpenes.

\subsection{Fungal Test Organisms}

The phytopathogenic fungus selected for this study is Macrophomina phoseolina the causal organism of charcoal rot disease. Macrophomina phaseolina was isolated from the diseased Maize plant. The fungal pathogen was maintained on potato dextrose agar (Himedia) at $26-28^{\circ} \mathrm{C}$. The fungal spores were collected from the 10 days old culture of the pathogens by flooding culture plates with $5 \mathrm{ml}$ of sterile distilled water and conidia were dislodged by using L-shaped glass rod. Conidial suspension was filtered through sterile double layered muslin cloth to remove bits of mycelia and suspended uniformly in the broth. The fungal inoculum was quantified by counting the number of spores using Haemocytometer slide and their number was adjusted to $1 \times 10^{6} \mathrm{ml}^{-1}$ of the suspension.

\subsection{Antifungal Activity Assay}

\subsubsection{Minimum Inhibitory Concentration (MIC)}

Antifungal activity was determined by Microdilution assay. The MIC is to determine the lowest concentration of an antifungal agent that appears to inhibit growth of the fungus[16]. Residues of different extracts were dissolved in respected solvents to a concentration of $10 \mathrm{mg} / \mathrm{ml}$. The plant extracts $(100 \mu \mathrm{l})$ were serially diluted $50 \%$ with water in 96 
well flat bottomed microtitre plates. Fungal cultures were transferred into fresh Potato dextrose broth, and $100 \mu 1$ of this was added to each well, $40 \mu 1$ of 2, 3, 5- triphenyltetrazolium chloride[TTC] dissolved in water was added to each of the micro plate wells, as growth indicator. Nystatin is used as reference antibiotic and positive control, and appropriate solvent blanks were included. The micro plates were covered with a cling film and incubated for $2-3$ days at $26^{\circ} \mathrm{C}$ and at $100 \%$ relative humidity[17]. The MIC was recorded by visual analysis in microtitre plate wells, where the lowest concentration of the plant extract that inhibited fungal growth after 48 to 72 hours of incubation will not change its colour to formazen dye.

\subsubsection{Direct Bioautography Method}

Bioautography method was developed to determine active compounds. Aluminium-backed TLC plates (ALUGRAM ${ }^{\circledR}$ SIL G/UV254, MACHERY-NAGEL) were loaded with $20 \mu \mathrm{l}$ of $100 \mu \mathrm{g}$ extracts. The plates were developed in 3 different mobile systems:

Ethylacetate/ methanol/ water[40:5.4:5] (polar

/neutral)[EMW]

Chloroform/ ethyl acetate/ formic acid[5:4:1] (intermediate polar/acidic)[CEF]

Benzene/ ethanol/ ammonium hydroxide[90:10:1]

(non-polar/basic)[BEA][11]

The chromatograms were dried for complete removal of solvents. Potato dextrose broth was prepared and cultures were transferred into broth from agar with a sterile swab. About $25-50 \mathrm{ml}$ of inoculum spray solution was prepared containing approximately $3 \times 10^{4}$ spores $/ \mathrm{ml}$ of actively growing fungi. The plates were sprayed lightly 3 times with spore suspension and incubated for $24 \mathrm{hr}$ in darkness in a moist chamber at $26^{\circ} \mathrm{C}$ and then sprayed with $20 \mathrm{mg} / \mathrm{ml}$ of TTC in boiling water and further incubated overnight. Fungal growth inhibition appeared as clear zones against a dark background[18].

\section{Results}

The solvent extractant methanol yielded most of the crude extract from Chromolaena odorata yielding $2900 \mathrm{mg} / \mathrm{ml}$ followed by Passiflora foetida yielding
$1840 \mathrm{mg} / \mathrm{ml}$. Oxalis corniculata, Antigonon leptopus and Ageratum conyzoides has a reasonably good extraction yield of $1670 \mathrm{mg} / \mathrm{ml}, 1440 \mathrm{mg} / \mathrm{ml}$ and $1380 \mathrm{mg} / \mathrm{ml}$ respectively from methanol extract. Compared to methanol, chloroform extractant yielded less quantity of crude extract which ranged from 100-620mg/ml (Figure 1).

The phytochemical tests were carried out to test the presence of primary and secondary metabolites (Table 1). Tests revealed the presence of Tannins, glycosides, proteins and flavanoids in all the tested extracts. In addition to this, the presence of alkaloids and saponins were recorded in Ageratum conyzoides. Steroids in Antigonon leptopus, Saponins in Chromolaena odorata, Alkaloids and saponins in Oxalis corniculata, Steroids in Passiflora foetida.

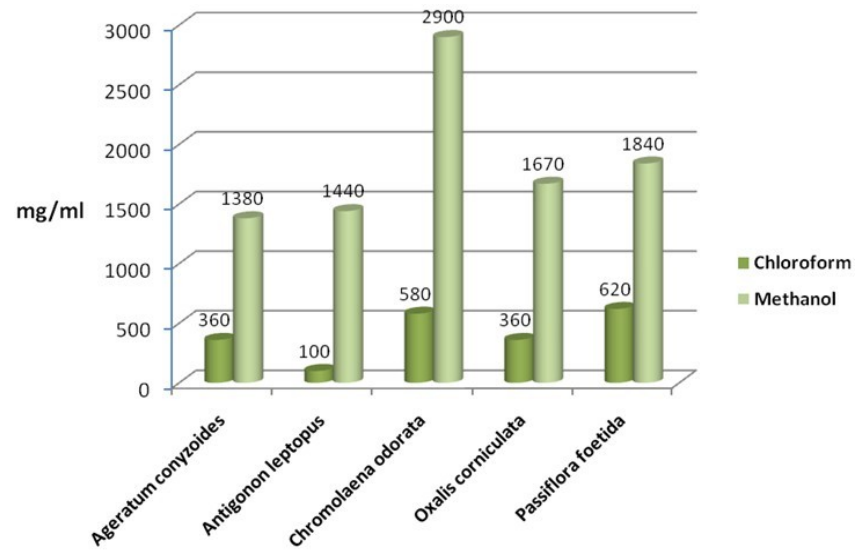

Figure 1. Quantity of samples extracted by solvents used in $\mathrm{mg} / \mathrm{ml}$.

The MIC was carried out in 96 well flat bottom microtitre plates to record the minimum inhibition concentration of extract at which the activity of the pathogen will be inhibited. The lower the MIC value is, the more active the extract is. The leaf extract of Oxalis corniculata had promising antifungal activity with a low MIC value of $0.078 \mathrm{mg} / \mathrm{ml}$ when compared to the other species extracts tested. Antigonon leptopus extract was relatively active with an MIC value of $0.625 \mathrm{mg} / \mathrm{ml}$. There was no inhibition of growth in wells of methanol used as our solvent blank, which means methanol did not have effect on the tested organism, proving it good solvent system for bioassays. The solvent extract chloroform did not show any activity against the test organism (Table 2).

Table 1. Phytochemical tests revealed the presence of following compounds tested in the screened invasive plant species.

\begin{tabular}{|c|c|c|c|c|c|c|}
\hline Compounds & Tests & $\begin{array}{c}\text { Ageratum } \\
\text { conyzoides }\end{array}$ & $\begin{array}{c}\text { Antigonon } \\
\text { Leptopus }\end{array}$ & $\begin{array}{c}\text { Chromolaena } \\
\text { odorata }\end{array}$ & $\begin{array}{c}\text { Oxalis } \\
\text { corniculata }\end{array}$ & $\begin{array}{c}\text { Passiflora } \\
\text { foetida }\end{array}$ \\
\hline Tannins & $\mathrm{FeCl}_{3}$ test & + & + & + & + & + \\
\hline Alkaloids & Dragondroff's test & + & - & - & + & - \\
\hline Saponins & Frothing test & + & - & + & + & - \\
\hline Cardiac glycosides & Keller-kiliani test & + & + & + & + & + \\
\hline Steroids & Liebermann-Burchardreaction & - & + & - & - & + \\
\hline Flavanoids & NaOH solution test & + & + & + & + & + \\
\hline Proteins & Xanthoproteic test & + & + & + & + & + \\
\hline Triterpenes & Salkowski test & - & + & - & & + \\
\hline
\end{tabular}

+: presence of compound ; $\quad$-: absence of compound 
Total activity of a plant is the quantity of material extracted from $10 \mathrm{gm}$ of dried plant material divided by the MIC value obtained[6]. It indicates the largest volume to which the biologically active compounds in $10 \mathrm{gm}$ of plant material can be diluted and still inhibits the growth of the test organism. The extracts of Antigonon leptopus and Oxalis corniculata exhibited the highest total activity of 2304 $\mathrm{ml}$ and $2141 \mathrm{ml}$ respectively (Table 3 ). Which means the extract can be diluted with $2.3 \mathrm{~L}$ and $2.1 \mathrm{~L}$ of the solvent or water and still inhibit the growth of M. phoseolina.

Table 2. MIC values in $\mathrm{mg} / \mathrm{ml}$ of selected invasive plant species after $48 \mathrm{hrs}$ of incubation

\begin{tabular}{|c|c|c|}
\hline \multirow{2}{*}{ Plant species } & Solvents & $\begin{array}{c}\text { MIC values in } \\
\mathbf{~ m g / m l}\end{array}$ \\
\hline \multirow{2}{*}{ Ageratum conyzoides } & Chloroform & - \\
\cline { 2 - 3 } & Methanol & 1.25 \\
\hline \multirow{2}{*}{ Antigonon leptopus } & Chloroform & - \\
\cline { 2 - 3 } & Methanol & 0.625 \\
\hline \multirow{2}{*}{ Chromolaena odorata } & Chloroform & - \\
\cline { 2 - 3 } & Methanol & 2.5 \\
\hline \multirow{2}{*}{ Oxalis corniculata } & Chloroform & - \\
\cline { 2 - 3 } & Methanol & 0.078 \\
\hline \multirow{2}{*}{ Passiflora foetida } & Chloroform & - \\
\cline { 2 - 3 } & Methanol & 1.25 \\
\hline
\end{tabular}

Table 3. Total activity of MIC values of tested extracts of different invasive plant species

\begin{tabular}{|c|c|c|c|}
\hline Plant species & $\begin{array}{c}\text { Mass in } \\
\mathbf{m g}\end{array}$ & $\begin{array}{c}\text { MIC in } \\
\mathbf{m g} / \mathbf{m l}\end{array}$ & Total activity in ml \\
\hline Ageratum conyzoides & 1380 & 1.25 & 1104 \\
\hline Antigonon leptopus & 1440 & 0.625 & 2304 \\
\hline Chromolaena odorata & 2900 & 2.5 & 1160 \\
\hline Oxalis corniculata & 1670 & 0.078 & 2141 \\
\hline Passiflora foetida & 1840 & 1.25 & 1472 \\
\hline
\end{tabular}

Direct Bioautography was carried out to test the zone of inhibition on TLC plates by using TTC as growth indicator. Bioautography worked well for most of the tested extracts except Passiflora foetida. Antigonon leptopus extract was active with a clear zone on TLC bioautogram of the tested organism indicating three zones of growth inhibition (Figure 2). In $P$. foetida there was growth but no inhibition was observed even though MIC values indicated antifungal activity. The non-activity of this extract in bioautography could be explained by volatilization or oxidation of antifungal compounds during an extended removal of the TLC eluents or by the disruption of synergism between active constituents caused by TLC.

Bioautography results of the TLC plates developed with the solvent system BEA showed clear zones or bands of inhibition. The degree of inhibition of Antigonon leptopus extract was higher with three active bands of zones of inhibition at $\mathrm{R}_{\mathrm{f}}$ value of $0.779,0.468$ and 0.276 in BEA mobile system (Figure 3). Ageratum conyzoides showed inhibition at 0.083 (Figure 2). Chromolaena odorata larger zone of inhibition at $\mathrm{R}_{\mathrm{f}} 0.275$ (Figure 4). Oxalis corniculata showed inhibition at 0.796 (Figure 5).

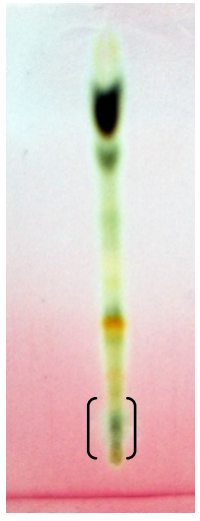

Figure 2. A. conyziodes

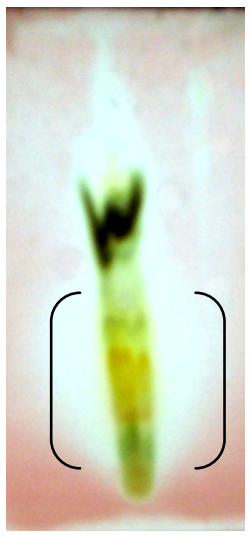

Figure 4. C. odorata $\mathrm{R}_{\mathrm{f}}$ value -0.272 $\mathrm{R}_{\mathrm{f}}$ value- 0.083 .

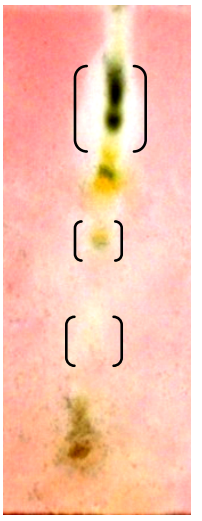

Figure 3. A. leptopus $\mathrm{R}_{\mathrm{f}}$ value- $0.276,0.468$ and 0.779 .

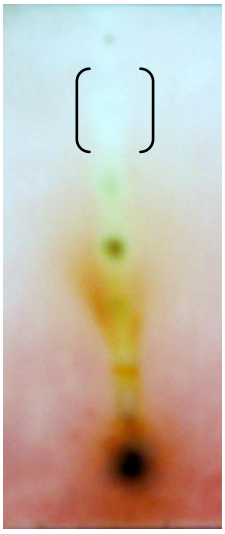

Figure 5. O. corniculata $\mathrm{R}_{\mathrm{f}}$ alue- 0.796

\section{Conclusions}

Plants make up the majority of the earth's living environment, they make up all the food on which humans and animals depend. Some of the fungal pathogens attack cultivated crops and make them diseased. Plant diseases may result in less food or of food in poor quality or may sometimes be poisonous and unfit for consumption. Some plant diseases may wipe out entire plant species. Controlling plant disease may result in better more food of better quality[8]. Since a decade people are using pesticides of toxic chemicals and even synthetic fungicides to control pathogens. The control of these fungi by synthetic fungicides is clouded by lots of drawbacks such as severe human and environmental toxicity effects and high costs. Their high costs make them less accessible particularly by rural farmers. These setbacks warrant an alternative source of fungicide. Plants and their secondary metabolites have shown great potential as antifungal source. Growing and harvesting promising plants would increase the costs substantially. Alien invasive plants known for their characteristic as aggressive growers, could aid in developing a less expensive plant source if explored for antifungal activity. The aim of the present investigate is to evaluate the antifungal properties of five invasive plant species against plant pathogenic fungi. 
The selected species (Ageratum conyzoides, Antigonon leptopus, Chromolaena odorata, Oxalis corniculata and Passiflora foetida) were evaluated using chloroform and methanol extractant and tested against plant pathogenic fungi Macrophomina phoseolina which causes charcoal rot disease in most of the cultivated plants. The part of the plant used was leaves, because leaves are the centers of intermediary metabolism leading to biologically active secondary metabolites. When the yield of the extractant was quantified, methanolic extract had large quantity of mass yield compared to chloroform. Chromolaena odorata methanol extract yielded $2900 \mathrm{mg} / \mathrm{ml}$ which is highest when compared to all other plant (Figure 1).

Antifungal assays were tested by using minimal inhibitory concentration and Bioautography technique. The MIC is determining the lowest concentration of an antifungal agent that appears to inhibit growth of the fungus. In this present study leaf extract of Oxalis corniculata had promising antifungal activity with a low MIC value of $0.078 \mathrm{mg} / \mathrm{ml}$ followed Antigonon leptopus which showed $0.625 \mathrm{mg} / \mathrm{ml}$ compared to the other species extracts tested (Table 2). The extracts of Antigonon leptopus and Oxalis corniculata exhibited the highest total activity of $2304 \mathrm{ml}$ and $2141 \mathrm{ml}$ respectively. Bioautography method was developed to determine active compounds[11, 19]. From the present study, the degree of inhibition of Antigonon leptopus extract was higher with an active band of $\mathrm{R}_{\mathrm{f}}$ value of 0.779 in BEA mobile system and other zones were at 0.468 and 0.276 .

The present investigation has demonstrated the antifungal activity of all the plants tested. This work proves that some invasive plants have potential and could be useful in combating plant fungal pathogens[6]. The use of plant extracts could enable the development of inexpensive and environmentally acceptable fungicides based on locally available natural products. Considering this, strict regulation should be set in place to avoid complete eradication of these plants. Isolation and characterization of active compounds is in progress.

\section{REFERENCES}

[1] IUCN, 2000. IUCN Guidelines for the prevention of Biodiversity loss caused by Alien InvasiveSpecies. Prepared by the SSC Invasive Species Specialist GroupApproved by the 51 st Meeting of the IUCN Council, Gland Switzerland, February 2000

[2] Reddy, C.S., Bhagyanarayana, G., Reddy, K.N. and Raju, V.S. 2008. Invasive alien flora of India. National Biological Information Infrastructure, USA

[3] Reddy, C.S., 2008. Catalogue of Invasive alien flora of India. Life Science Journal, 5(2):84-89

[4] Ripu, M.K. 2003. Invasive alien plants and Eupatorium:
Biodiversity and livelihood. Himalayan Journal of sciences, 1(2):129-133

[5] Tripathi, R.S., 2009. Alien Plant Invasion: A Hot Ecological Issue. International Society of Environmental Botanist, 15(3)

[6] Mdee, L.K., Masoko, P. and Eloff, J.N. 2009. The activity of extracts of seven common invasive plant species on fungal phytopathogens. South African Journal of Botany, doi:10.1016/j.sajb.2009.02.003

[7] Dabur, R., Gupta, A., Mandal, T.K., Singh, D.D., Bajpai, V., Gurav, A.M. and Lavekar, G.S. 2007. Antimicrobial activity of some Indian medicinal plants. African Journal of Tradition, CAM. 4(3):313-318

[8] Agrios, G.N. 1997. Plant pathology, fourth edition. Academic press

[9] Bindu, S. and Kumar, P. 2009. In-vitro antifungal potency of some plant extracts against Fusarium oxysporum. International Journal of Green Pharmacy, 63-65

[10] Jack, I.R. and Orubike, O.K. 2008. Phytochemical analysis and antimicrobial activity of the extract of leaves of fleabane (Conyza sumatrensis). Journal of applied science and environmental management, 12(4): 63-65

[11] Masoko, P. and Eloff, J.N. 2005. The diversity of antifungal compounds of six South African Terminalia species[Combretaceae] determined by Bioautography. African Journal of Biotechnology, 4(12):1425-31

[12] Raghavendra, M.P., Satish, S. and Raveesha K.A. 2006. Phytochemical analysis and antibacterial activity of Oxalis corniculata; a known medicinal plant. My Science, 1(1):72-78

[13] Satish, S., Mohana, D.C., Raghavendra, M.P. and Raveesha, K.A. 2007. Antifungal activity of some plant extracts against important seed borne pathogens of Aspergillus spp. Journal of Agricultural Technology, 3(1):109-119

[14] Vital, P.G. and Rivera, W.L. 2009. Antimicrobial activity and cytotoxicity of Chromolaena odorata (L.f) King and Robinson and Uncaria perrottetii (A. Rich) Merr. extracts Journal of Medicinal plant Research, 3(7):511-518

[15] Harborne, J.B. 1973. Phytochemical Methods: A guide to Modern Techniques of Plant Analysis, Chapman and Hall Ltd., London

[16] Andrews, J.N. 2001. Determination of Minimum inhibitory concentrations. Journal of Antimicrobial chemotherapy, 48(SI):5-16

[17] Eloff, J.N. 1998. A sensitive and quick Microplate method to determine the Minimal inhibitory concentration of Plant extracts of Bacteria. PlantaMedica, 64:711-713

[18] Guleria, S. and Kumar, A. 2006. Antifungal activity of some Himalayan medicinal plants using direct Bioautography. Journal of Cell and Molecular Biology, 5:95-98

[19] Masoko, P. and Eloff, J.N. 2006. Bioautography indicates the multiplicity of antifungal compounds from 24 Southern African Combretum species[Combretaceae]. African Journal of Biotechnology, 5(18):1625-47 